$C$ in equation (3) would be $4.07 \times 10^{-5}$ ST units ${ }^{3}$. Vacuum deposited polycrystalline anthracene films produced in this laboratory give results consistent with Schottky emission across grain boundaries, with $\Delta E=1.9 \mathrm{eV}$.

We thank Dr T. F. Palmer and Mr C. Lewis of the Department of Chemistry, University of Nottingham, for performing the mass spectrometric and fluorescence measurements, and Professor D. D. Eley and Dr M. R. Willis of the same department for many helpful discussions.

K. Morgan

Electrical Matcrials Laboratory, R. Pethig*

Electrical Engineering Department,

University of Southampton.

Received February 27; revised May 20, 1969.

* Present address: Department of Chemistry, University of Nottingham.

1 Morgan, K., and Pethig, R., Nature, 219, 478 (1968).

2 Nakada, I., and Ishihara, Y., J. Phys. Soc. Japan, 19, 695 (1964).

'Johansen, T. T., J. Appl. Phys., 37, 499 (1966).

- Helfrich, W., and Schneider, W. G., J. Chem. Phys., 44, 2902 (1966).

${ }^{5}$ Blakemore, J. S., Semiconductor Statistics (Pergamon Pross, 1962).

6 Helfrich, W., and Mark, P., Z. Physik, 171, 527 (1963).

'Schmillen, A., and Falter, W. W., Z. Physik, 218, 401 (1969).

\section{Effect of Reactor Irradiation on the Internal Surface Area of Corrosion Films on Zirconium Alloys}

THE corrosion of zirconium alloys can, in certain circum. stances, be enhanced by reactor radiation. The parameters controlling the enhancement are incompletely understood and work is in progress in several laboratories to clucidate possible mechanisms. At Harwell one approach has been to study the effect of reactor radiation on the surface area of corroding specimens. The preliminary results show interesting trends.
The results are summarized in Table 1, where the degree of corrosion of each specimen is expressed as the increase in weight for unit geometric area $\left(1 \mathrm{dm}^{2}\right)$ of the specimen. The surface area figures are given on the basis of specimens of the same geometric area. The experiments have incorporated a range of different corrodents, pretreatments, corrosion temperatures and alloys, but despite this variation an important general conclusion is immediately apparent-that irradiation consistently increases the surface area. Thus the surface areas of specimens corroded in the absence of radiation are all below $4 \mathrm{dm}^{2}$ whereas after irradiation values range from $4 \cdot 2$ to 82 .

In the absence of radiation the surface area increases rapidly from $\sim 1 \mathrm{dm}^{2}$ for the unoxidized metal and remains approximately constant (that is, between 1.8 and $3.6 \mathrm{dm}^{2}$ ) for oxidized samples having weight increases ranging from $9 \mathrm{mg} \mathrm{dm}^{-2}$ up to $141 \mathrm{mg} \mathrm{dm}^{-2}$. There seems to be no change in surface area associated with the major transition in the corrosion kineties which typically occurs at $\sim 30 \mathrm{mg} \mathrm{dm}-2$ in this system. This is surprising, for the transition is eommonly thought to represent a breakdown of the outer layers of the oxide, giving a layer of porous oxide which increases in thickness as corrosion proceeds further. The present results seem to imply that this interpretation is incorrect, at least for these corrodents.

The irradiated specimens show quite different behaviour. In general terms the surface area increases steadily as the corrosion progresses and in several cases the ratio of surface area to weight gain is approximately unity. It is interesting that high values of surface area were found even for specimens which had been preoxidized. Most of their corrosion had taken place in the absence of radiation and it eppears that only a relatively short irradiation period is sufficient to increase the surface area dramatically (though in these cases the ratio of surfece area to weight gain was rather less than unity).

Further work is in progress to clarify in detail the profound effects of radiation on the structure of the oxide film. Our preliminary observations are consistent with the suggestion ${ }^{4}$ that the cnhancement of corrosion

\begin{tabular}{|c|c|c|c|c|}
\hline \multicolumn{5}{|c|}{ In absence of radiation } \\
\hline $\begin{array}{l}\text { Weight } \\
\text { gaim } \\
\text { ang } \mathrm{dm}^{-2}\end{array}$ & $\begin{array}{l}\text { Surface } \\
\text { area* } \\
\mathrm{dm}^{2}\end{array}$ & $\begin{array}{l}\text { Pre-oxidation } \\
\text { at } 450^{\circ} \mathrm{C}\end{array}$ & Corrosion conditions & Alloy \\
\hline 0 & $1 \cdot 1$ & None & None & Zirc-2 \\
\hline 9 & $3 \cdot 6$ & None & $\mathrm{CO}_{2} / \mathrm{H}_{2} \mathrm{O} /$ air $300^{\circ} \mathrm{C} ; 66$ days & Zirc-2 \\
\hline 16 & $2 \cdot 7$ & None & $\mathrm{D}_{2} \mathrm{O}$ steam $340^{\circ} \mathrm{C} ; 22$ days & Zirc-2 \\
\hline 60 & $3 \cdot 1$ & None & $\mathrm{H}_{2} \mathrm{O}$ steam $480^{\circ} \mathrm{C} ; 6$ days & Zirc-2 \\
\hline 66 & $3 \cdot 3$ & Yone & $\mathrm{H}_{2} \mathrm{O}$ steam $350^{\circ} \mathrm{C} ; 28$ days & Zirc-2 \\
\hline 90 & $2 \cdot 3$ & For 6 days & $\mathrm{H}_{2} \mathrm{O}$ steam $300^{\circ} \mathrm{C} ; 62$ days & Zire-2 \\
\hline 92 & $3 \cdot 3$ & For 6 days & $\mathrm{H}=\mathrm{O}$ steam $300^{\circ} \mathrm{C} ; 62$ days & Zirc-2 \\
\hline 141 & $1 \cdot 8$ & For 6 days & $\mathrm{H}_{2} \mathrm{O}$ steam $340^{\circ} \mathrm{C} ; 35$ days & Zirc-2 \\
\hline
\end{tabular}

The surface sireas studied were quite small (down to $\sim 1 \mathrm{~cm}^{2}$ ) and they were determined by the BET proccdure ${ }^{1}$ from the adsorption of $\mathrm{Xe}^{133}$ at $77^{\circ} \mathrm{K}$ using a technique based on that of Chenébault and Schürenkämper ${ }^{2}$.

Two zirconium alloys have bec $n$ studic d, Zircaloy- 2 and $\mathrm{Zr} 2.5$ per cent $\mathrm{Nb}$ alloy. The specimens were tubes $0 \cdot 61$ em diameter, $0.635 \mathrm{~cm}$ long and $0.05 \mathrm{~cm}$ thick, corroded at temperatures in the range $300^{\circ}-480^{\circ} \mathrm{C}$ in corrodents which were basically steam or moist $\mathrm{CO}_{2} 10$ per cent air mixture by volume ${ }^{3}$. In some instances long corrosion times were simulated by giving the specimens a preoxidation treatment for a short period at a higher temperature $\left(450^{\circ} \mathrm{C}\right)$ followed by a long period at the lower temperature of interest (for example, $300^{\circ} \mathrm{C}$ ) to eliminate any "memory" of the higher temperature treatment. The corrosion of specimens under radiation was carried out in the reactor DIDO $\left(\sim 3 \times 10^{13}\right.$ neutrons $\mathrm{cm}^{-2} \mathrm{~s}^{-1}$ $\left.>1 \mathrm{MeV} ; 10^{8}-10^{9} \mathrm{R}^{-1} \gamma\right)$ in equipment already described $^{3}$.
Table 1

\begin{tabular}{|c|c|c|c|c|}
\hline \multirow[b]{2}{*}{$\begin{array}{l}\text { Weight } \\
\text { gain } \\
\text { mg dm}^{-2}\end{array}$} & \multicolumn{3}{|r|}{ Under radiation } & \multirow[b]{2}{*}{ Alloy } \\
\hline & $\begin{array}{l}\text { Surface } \\
\operatorname{area}^{*} \\
\mathrm{dm}^{2}\end{array}$ & $\begin{array}{l}\text { Pre-oxidation } \\
\text { at } 450^{\circ}\end{array}$ & ('orrosion conditions & \\
\hline $\begin{array}{r}15 \\
16 \\
18 \\
28 \\
40 \\
43 \\
85 \\
152 \\
180\end{array}$ & $\begin{array}{l}9 \cdot 1 \\
4 \cdot 2 \\
16 \\
21 \\
31 \\
42 \\
23 \\
82 \\
77\end{array}$ & $\begin{array}{l}\text { None } \\
\text { None } \\
\text { None } \\
\text { None } \\
\text { None } \\
\text { None } \\
\text { For } 6 \text { days } \\
\text { For 6 days } \\
\text { For 6 days }\end{array}$ & $\begin{array}{l}\mathrm{D}_{2} \mathrm{O} \text { steam } 340^{\circ} \mathrm{C} ; 22 \text { days } \\
\mathrm{D}_{2} \mathrm{O} \text { steam } 340^{\circ} \mathrm{C} ; 22 \text { days } \\
\mathrm{CO}_{2} / \mathrm{H}_{2} \mathrm{O} / \text { air } 300^{\circ} \mathrm{C} ; 66 \text { days } \\
\mathrm{CO}_{2} / \mathrm{H}_{2} \mathrm{O} / 2 \text { air } 300^{\circ} \mathrm{C} ; 66 \text { days } \\
\mathrm{D}_{2} \mathrm{O} \text { stean }+\mathrm{O}_{2} 340^{\circ} \mathrm{C} ; 105 \text { days } \\
\mathrm{D}_{2} \mathrm{O} \text { steam }+\mathrm{O}_{2} 340^{\circ} \mathrm{C} ; 105 \text { days } \\
\mathrm{H}_{2} \mathrm{O} \text { steam }+\mathrm{O}_{2} 300^{\circ} \mathrm{C} ; 74 \text { days } \\
\mathrm{H}_{2} \mathrm{O} \text { steam }+\mathrm{O}_{2} 300^{\circ} \mathrm{C} ; 74 \text { days } \\
\mathrm{H}_{2} \mathrm{O} \text { steam }+\mathrm{O}_{2} 300^{\circ} \mathrm{C} ; 74 \text { days }\end{array}$ & 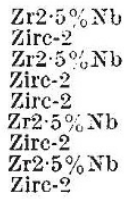 \\
\hline
\end{tabular}

obscrved in these systems results, at least in part, from irradiation embrittlement of the film, which lends to extensive breakdown and so to an increase in internal surface area.

\section{R. C. Asher}

J. F. White

Applicd Chemistry Division,

A.ERE,

Harwell, Berkshire.

Jeceived February 17; revised May 14, 1969.

${ }^{2}$ Sing, K. S. W., and Greeg, S. J., Adsorption Surface Area and Porosity (Academic Press, 1967).

${ }^{2}$ Chenébault, P., and Schürenkämper, A., J. Phys. Chem., 69, 2300 (1965).

Asher, R. C., Hall, A., Howard, C., and Kirstein, T. B. A., Nuclear Engineering, May 1964

4 Asher, R. C., Davies, D., Hall, A., Kirstein, T. B. A., Marriott, J. W., and White, P. J., Electrochem. Tech., 4 (5-6), 231 (1966). 